ciated in the past and Gordon (1968) stated that it occurs as a result of the direct toxic action of the local anaesthetic agent on the fetal myocardium and is not a sign of fetal asphyxia. Teramo (1969) found a correlation between fetal bradycardia and a decrease in the fetal $p H$ after paracervical block; he concluded that fetal bradycardia after paracervical block is sufficient to cause hypoxia. Two perinatal deaths occurred after paracervical block, both babies being stillborn.

At necropsy both babies were shown to have fetal tissue levels of bupivacaine about 10 times the expected normal levels, indicating massive accumulation in the fetal circulation (F. Reynolds, personal communication, 1969). Gordon (1968) showed that after a paracervical block the local anaesthetic agent can be absorbed from the paracervical tissues and that it reaches a peak concentration in the maternal circulation after 20 minutes; after crossing the placenta the peak fetal concentration is reached 30 minutes after the block. Shnider et al. (1968) considered that some of the local anaesthetic agent could reach the placenta direct from the paracervical tissues. Page et al. (1961) and Teramo and Widholm (1967) noted the possibility of accidental injection of local anaesthetic agent direct into the fetus during insertion of the paracervical block. The high fetal accumulation of bupivacaine in the two stillbirths could have occurred by any of these routes.

The first fetal death followed the accepted pattern (Whitehouse, 1968), but the second is difficult to explain. It is suggested that the accumulation of bupivacaine may have occurred more slowly in the second fetus and that placental vasoconstriction and a decrease in placental blood flow took place. Teramo and Widholm (1967) postulated that mepivacaine may interfere with placental blood flow and cause vasoconstriction. Rosefsky and Petersiel (1968) showed that the fetus is unable to metabolize local anaesthetic agent and is dependent on the placenta for its removal. Thus bupivacaine may have accumulated and been retained in the fetus and as labour progressed an increase in fetal acidosis could be expected. In the presence of acidosis the cardiotoxic effects of bupivacaine would be potentiated and could have resulted in acute fetal cardiac failure (Steinhaus, 1957).
In this assessment of paracervical block for routine use in labour we have found the following disadvantages: (a) a low rate of success with continuous block, (b) a high incidence of maternal haemorrhage during insertion of the continuous block needle, and (c) a high incidence of fetal bradycardia together with two perinatal deaths.

In conclusion, we recommend that continuous block in the present form should be discontinued and that the amide-type local anaesthetic agents, of which bupivacaine is one, should not be used for single paracervical nerve block.

We wish to thank Dr. R. Ollerenshaw, department of medical illustration, Manchester Royal Infirmary, for his help with the illustrations. We are indebted to Dr. Felicity Reynolds, department of pharmacology and therapeutics, St. Thomas's Hospital Medical School, London, for estimating the tissue levels of bupivacaine in the two stillbirths and for her helpful comments.

\section{REFERENCES}

Cooper, K. V., and Moir, J. C. (1963). British Medical fournal, 1, 1372. Cooper, K. V., Gilroy, K. J., and Hurry, D. J. (1968). Fournal of Obstetrics and Gynaecology of the British Commonwealth, 75, 863. Davis, J. E., Frudenfeld, J. C., Frudenfeld, K., and Webb, A. N. (1962). Obstetrics and Gynecology, 19, 195.

Freeman, D. W., Bellville, T. P., and Barno, A. (1956). Obstetrics and Gynecology, 8, 270.

Gellert, P. (1926). Monatsschrift für Geburtshilfe and Gynäkologie, 73, 143.

Gordon, H. R. (1968). New England Fournal of Medicine, 279, 910.

Gudgeon, D. H. (1968). British Medical fournal, 2, 403.

Hollmén, A., Oiala, A., and Korhonen, M. (1969). Acta Anaesthesiologica Scandinavica, 13, 1 .

Jung, H., Konecky, P., and Klöck, F. K. (1969). Geburtshilfe und Frauenheilkunde, 29, 174.

Kuah, K. B., and Yates, M. J. (1967). Lancet, 1, 1159. Kuah, K. B., and Yates, M. J. (1967). Lancet, 1, 1159.

fournal of Obstetrics and Gynecology, 81, 1094.
Picton, F. C. R. (1969). British fournal of Clinical Practice, 23, 162.

Rosefsky, J. B., and Petersiel, M. E. (1968). New England fournal of Medicine, 278, 530 .

Shnider, S. M., Asling, J. P., Margolis, A. J., Wey, E. L., and Wilkinson, G. R.' (1968). New England Fournal of Medicine, 279, 947

Steinhaus, J. E. (1957). Anesthesiology, 18, 275.

Stockhausen, H. (1967). Deutsche medizinische Wochenschrift, 92, 2220.

Tafeen, C. H., Freedman, H. L., and Harris, H. (1966). American fournal of Obstetrics and Gynecology, 100, 55 .

Teramo, K. (1969). Fournal of Obstetrics and Gynaecology of the British Commonwealth, 76, 881.

Teramo, K., and Widholm, O. (1967). Acta Obstetricia et Gynecologica Scandinavica, 46, Suppl. No. 2.

Whitehouse, D. B. (1968). British Medical fournal, 2, 764.

\title{
Plasma Magnesium Concentration in Primary Hyperparathyroidism
}

\author{
R. A. L. SUTTON, ${ }^{*}$ B.M., M.R.C.P.
}

\begin{abstract}
Ummary : The plasma magnesium concentration has $\checkmark$ been determined in 73 patients with primary hyperparathyroidism. In most patients it lay within the normal range $(1.7-2.3 \mathrm{mg} . / 100 \mathrm{ml}$.$) , but in five it was less than$ $1.6 \mathrm{mg} . / 100 \mathrm{ml}$. These patients had relatively high urinary magnesium outputs, and one of them, studied in greater detail, failed to retain parenterally administered magnesium. Hence hypomagnesaemia in hyperparathyroidism may be associated with a defect in renal magnesium conservation, which may be reversible.
\end{abstract}

* Senior Medical Registrar, University College Hospital, London W.C.1.
The parathyroid glands have for many years been known to
influence magnesium metabolism. Bulger and Gausmann (1933)
noted that a negative magnesium balance accompanied primary
hyperparathyroidism with osteitis fibrosa; they and many sub-
sequent workers observed a positive magnesium balance, asso-
ciated with a fall in the plasma magnesium concentration, after parathyroidectomy in such patients. Parathyroid hormone has been shown to increase renal tubular magnesium reabsorption in rats (MacIntyre et al., 1963) and in man (Shelp et al., 1966). MacIntyre et al. (1963) postulated a central role for the para- 
thyroid glands in the regulation of the plasma magnesium concentration. The parathyroid gland of the goat has been shown to respond to perfusion with a solution containing a high magnesium concentration by decreasing its output of parathyroid hormone (Care et al., 1966).

Previous workers have found that the plasma magnesium concentration is usually within the normal range in primary hyperparathyroidism; no correlation has been reported between the concentrations of calcium and magnesium in the plasma in this condition. Hypomagnesaemia has, however, occasionally been noted preoperatively in primary hyperparathyroidism, especially in association with very high plasma calcium concentrations (Harmon, 1956; Barnes et al., 1957; Agna and Goldsmith, 1958; Hanna et al., 1961). The low plasma magnesium concentration has usually been taken to indicate magnesium deficiency, which has been variously attributed to anorexia, to vomiting, and to obligatory urinary magnesium losses (Hanna et al., 1961; Heaton, 1966).

In this study, which forms part of an investigation of magnesium metabolism in parathyroid disease, the concentration of calcium and magnesium has been measured in the plasma of 73 patients with primary hyperparathyroidism in order to determine whether the concentrations of these two ions are correlated, and whether the plasma magnesium concentration is different in the various clinical subgroups of patients with primary hyperparathyroidism. One case is reported in detail, being a further example of severe hypomagnesaemia in association with primary hyperparathyroidism.

\section{Patients Studied}

The patients comprised 71 consecutive adult cases of primary hyperparathyroidism investigated in the Metabolic Unit at University College Hospital and subsequently operated on by Mr. D. R. Davies. The two additional patients were operated on elsewhere. Patients with tertiary hyperparathyroidism (Davies et al., 1968) and those suffering from disorders-for example, chronic alcoholism-or taking drugs-for example, corticosteroids-known to alter the plasma calcium or magnesium concentration were not included. Plasma calcium and magnesium concentrations were determined in the same blood sample taken without venous stasis after an overnight fast. Calcium was measured by emission flame photometry and magnesium by absorption spectrophotometry (MacDonald and Watson, 1966). All plasma calcium values have been adjusted for variations in the serum proteins by the specific gravity correction recommended by Dent (1962) (See Dent and Watson, 1968). No correction has been applied to the plasma magnesium concentration, since it was found to be influenced much less than calcium by variations in plasma protein concentrations (Forbes, personal communication).

In the clinical classification of patients, osteitis fibrosa has been diagnosed in those with either $(a)$ subperiosteal erosions and a raised plasma alkaline phosphatase, or (b) cystic bone disease with or without a raised alkaline phosphatase.

\section{Results}

The plasma calcium concentration is maintained at a strikingly constant level in most patients with hyperparathyroidism (see, for example, Dent and Watson, 1968). Serial determinations suggested that the same was true of the plasma magnesium concentration. An attempt was made to compare the magnitude of the day-to-day fluctuations of these two ions. Forty patients had determinations of plasma calcium and magnesium, after an overnight fast, on two or more occasions before surgery. The range of variation of corrected plasma calcium concentration in each individual is expressed as follows. The highest and lowest plasma concentrations were selected, and their mean was calculated. The difference between these two calcium concentrations was then expressed as a percentage of the mean. This figure varied from 0 to $9.8 \%$, with an average of $3.4 \%$. Similar calculations for plasma magnesium concentration gave a range of variation from 0 to $16.2 \%$, with an average of $4.4 \%$. Thus the plasma magnesium concentration is almost as constant as the plasma calcium concentration in this group of patients under fasting conditions.

In the subsequent analysis the result of the first determination of calcium and magnesium after admission to hospital was taken as representative of each patient. The distribution of plasma magnesium concentrations in the 73 patients with primary hyperparathyroidism and in 60 local normal controls is shown in Fig. 1. These data on normal control subjects were

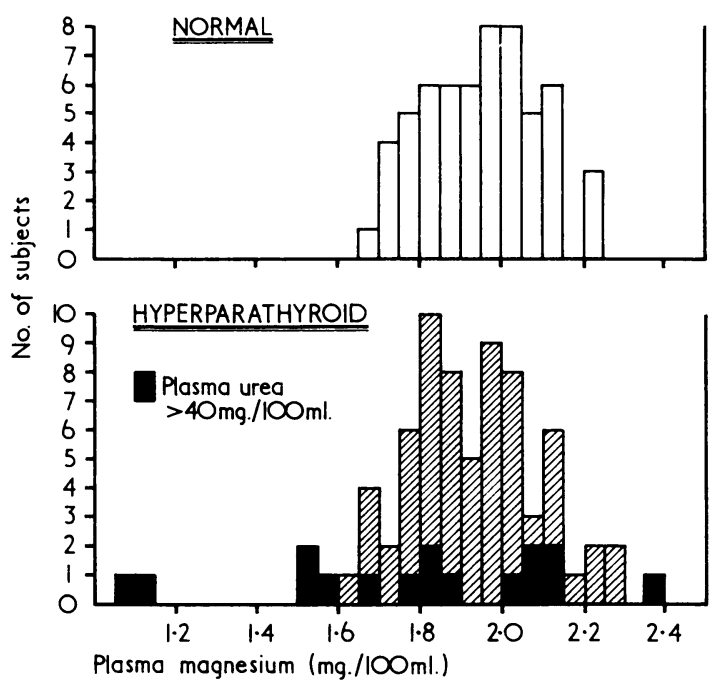

FIG. 1.-Distribution of plasma magnesium concentration in hyperparathyroid patients and in normal controls.

kindly made available by Mrs. M. A. Forbes (personal communication). The mean plasma magnesium concentration of the patients $(1.90 \mathrm{mg} . / 100 \mathrm{ml}$.$) is similar to that of the controls$ (1.95 mg./100 ml.). Six of the 73 patients, however, have plasma magnesium concentrations below the lower limit of the normal range.

Renal disease is known to affect magnesium metabolism, the plasma concentration rising when glomerular filtration becomes severely reduced (Clarkson et al., 1965; Steele et al., 1968). With the use of plasma urea concentration as a crude index of renal function, the group of 16 patients with plasma urea concentrations exceeding $40 \mathrm{mg} . / 100 \mathrm{ml}$. was separated from the remaining 57 patients without urea retention. This group of 16 patients includes five of the six with subnormal plasma magnesium concentrations. The mean plasma calcium and magnesium concentrations of the groups with and without urea retention are shown in Table I. The patients with urea retention have a significantly higher plasma calcium concentration $(t=3.58, P<0.01)$ and a significantly lower plasma magnesium concentration $(t=2.51, \mathrm{P}<0.01)$ than those with normal plasma urea levels.

Since primary hyperparathyroidism with osteitis fibrosa 
TABle I.-Plasma Calcium and Magnesium Concentrations in Patients With and Without Urea Retention

\begin{tabular}{l|r|r|r|r|r} 
& No. & Calcium & \multicolumn{2}{|l|}{ Magnesium } \\
\hline & & Mean & S.D. & Mean & S.D. \\
\hline Patients with plasma urea $>40 \mathrm{mg} / 100 \mathrm{ml}$. & 16 & 12.74 & 2.10 & 1.78 & 0.35 \\
Patients with plasma urea $>40 \mathrm{mg} / 100 \mathrm{ml}$ : & 57 & 11.45 & 0.93 & 1.93 & 0.15 \\
$\quad$ Total & 10 & 12.17 & 1.19 & 1.93 & 0.15 \\
Those with osteitis fibrosa & 47 & 11.29 & 0.79 & 1.93 & 0.15
\end{tabular}

tends to be associated with more severe renal impairment than hyperparathyroidism without osteitis fibrosa (Dent, 1962) it seemed possible that the lower plasma magnesium concentration in the group with urea retention might be related to the presence of osteitis fibrosa. In order to determine the effect of osteitis fibrosa independently of that of urea retention, the 57 patients without urea retention have been divided into two groups, with and without osteitis fibrosa, as shown in Table I. Though the plasma calcium concentration is significantly higher in the patients with osteitis fibrosa $(P<0.01)$, the plasma magnesium concentration is the same in these groups. It therefore appears that hypomagnesaemia is associated with renal impairment, as evidenced by urea retention, rather than with the presence or absence of osteitis fibrosa. Of the five patients with plasma magnesium concentrations less than $1.6 \mathrm{mg}$./ $100 \mathrm{ml}$., only two had osteitis fibrosa.

The urinary excretion of magnesium is usually normal in primary hyperparathyroidism (Sutton and Watson, 1969). The mean 24-hour urinary magnesium excretion of the five patients (all female) with the lowest plasma magnesium concentrations $(<1.6 \mathrm{mg} . / 100 \mathrm{ml}$.), all of whom had urea retention (blood urea $44-70 \mathrm{mg} . / 100 \mathrm{ml}$.) was $65 \mathrm{mg}$. (range $36-120 \mathrm{mg}$.); this is to be compared with a mean value of $101 \mathrm{mg}$. in control female subjects and $91 \mathrm{mg}$. in female patients with primary hyperparathyroidism. Since the kidneys of normal subjects conserve magnesium efficiently-that is, to less than $12 \mathrm{mg}$./day-during periods of magnesium deprivation (see Fitzgerald and Fourman, 1956; Dunn and Walser, 1966) there appears to be a defect in renal magnesium conservation in these hyperparathyroid patients with hypomagnesaemia. The mean daily urinary calcium excretion in this group of five patients was $254 \mathrm{mg}$. (range 68-747 mg).

The relation between the corrected plasma calcium and magnesium concentrations in the 73 patients is shown in Fig. 2.

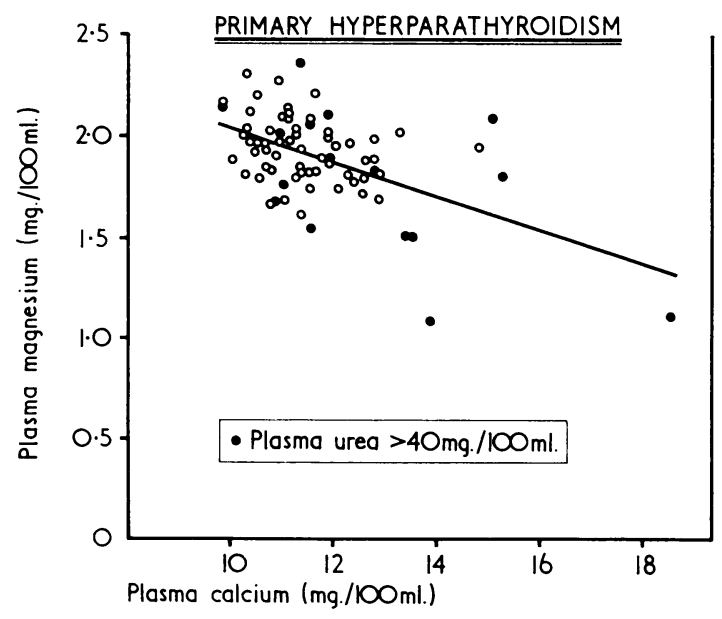

FIG. 2.- Relation between plasma calcium and magnesium concentrations in hyperparathyroid patients. Regression equation: magnesium $=-0.081 \times$ calcium +2.844 . $r=-0.506 . P<0.001$.
For the whole group there is a highly significant negative correlation between the plasma calcium and magnesium levels $(r=-0.506, P<0.001)$. The distributions of calcium and magnesium values, however, are not normal, and the outlying points exert a disproportionate effect on the correlation. Logarithmic plotting of the data does not result in a normal distribution. Nevertheless, even after exclusion of the outlying points as shown in Table II, a significant negative correlation between calcium and magnesium remains.

TABle II.-Relation Between Plasma Calcium and Magnesium Concentration in Patients With Primary Hyperparathyroidism

\begin{tabular}{l|l|l|l|c}
\hline & No. & $\mathrm{r}$ & $\mathrm{P}$ \\
\hline All patients $\ldots$ & 73 & -0.506 & $<0.001$ \\
Patients with plasma $\mathrm{Ca}<16 \mathrm{mg} / 100 \mathrm{ml}$. &.. & 72 & -0.356 & $<0.01$ \\
Patients with plasma $\mathrm{Ca}<13 \mathrm{mg} / 100 \mathrm{ml}$. & $\cdots$ & 65 & -0.300 & $<0.02$ \\
\hline
\end{tabular}

The following is the case report of one patient with severe hypomagnesaemia in whom more detailed studies of magnesium metabolism were undertaken.

\section{CASE REPort}

A woman aged 68 developed widespread Paget's disease in 1959. Hypercalcaemia was first detected in 1964 (plasma calcium 13.1 mg./100 ml.). She was admitted to University College Hospital, under the care of Dr. Lyal Watson, in September 1968, complaining of widespread bone pains, deafness in the right ear, tiredness, frequency of micturition, and constipation.

On examination she was a small frail woman (weight $42 \mathrm{~kg}$.) with a pronounced thoracic kyphosis, but no other physical abnormalities. Investigations showed: haemoglobin $12.5 \mathrm{~g} . / 100 \mathrm{ml}$., plasma calcium $13.9 \mathrm{mg}$. $/ 100 \mathrm{ml}$., inorganic phosphorus $2.2 \mathrm{mg}$./ $100 \mathrm{ml}$., alkaline phosphatase $47 \mathrm{King}$-Armstrong units/100 ml., magnesium $1.07 \mathrm{mg} . / 100 \mathrm{ml}$., urea $45 \mathrm{mg} . / 100 \mathrm{ml} . X$-ray films showed extensive Paget's disease and chondrocalcinosis articularis, but no evidence of osteitis fibrosa.

Calcium and magnesium balance studies were performed, according to the principles of Reifenstein et al. (1945) as modified by Dent et al. (1961). Barium sulphate was used as an internal stool marker (Dick, 1967). During two four-day control periods faecal calcium exceeded dietary intake, and there was a mean daily negative calcium balance of $326 \mathrm{mg}$. On a magnesium intake of 145 mg. a day faecal excretion averaged $79 \mathrm{mg}$. and urinary excretion $86 \mathrm{mg}$., giving a mean daily negative magnesium balance of $20 \mathrm{mg}$. During a third balance period an intravenous infusion of $492 \mathrm{mg}$. of magnesium as magnesium sulphate in 1 litre of $5 \%$ dextrose was given over a 6 -hour period. During 48 hours from the beginning of the infusion urinary magnesium excretion was $555 \mathrm{mg}$; the mean daily magnesium balance for the whole fourday period was minus $9 \mathrm{mg}$. Thus none of the infused magnesium was retained. The plasma magnesium concentration rose from 1.26 to $3.18 \mathrm{mg} . / 100 \mathrm{ml}$. during the infusion, and the plasma calcium concentration rose from 14.9 to $15.4 \mathrm{mg}$. $/ 100 \mathrm{ml}$. Four davs later the plasma magnesium had fallen to $1.18 \mathrm{mg} . / 100 \mathrm{ml}$. and the calcium to $14.5 \mathrm{mg} . / 100 \mathrm{ml}$.

During a standard hydrocortisone test (Dent and Watson, 1968) the plasma calcium level fell from 14.6 to $12.2 \mathrm{mg}$. $/ 100 \mathrm{ml}$., which was thought to support a diagnosis of hyperparathyroidism. On 23 October Mr. D. R. Davies removed a parathyroid adenoma weighing $16 \mathrm{~g}$., and identified three other normal parathyroid glands. The plasma calcium, magnesium, phosphorus, and alkaline phosphatase levels before and after operation, together with the treatment given during this time, are given in Fig. 3. Magnesium supplements were not given, since the plasma magnesium concentration fell below $1 \mathrm{mg} . / 100 \mathrm{ml}$. on only a single occasion and there were no symptoms which could be attributed to magnesium deficiency

In March 1969, when her only treatment was dihydrotachysterol $0.5 \mathrm{mg}$. daily, the plasma calcium concentration was 9.3 mg./100 ml., magnesium $1.70 \mathrm{mg} . / 100 \mathrm{ml}$., and urea $49 \mathrm{mg} . / 100$ 


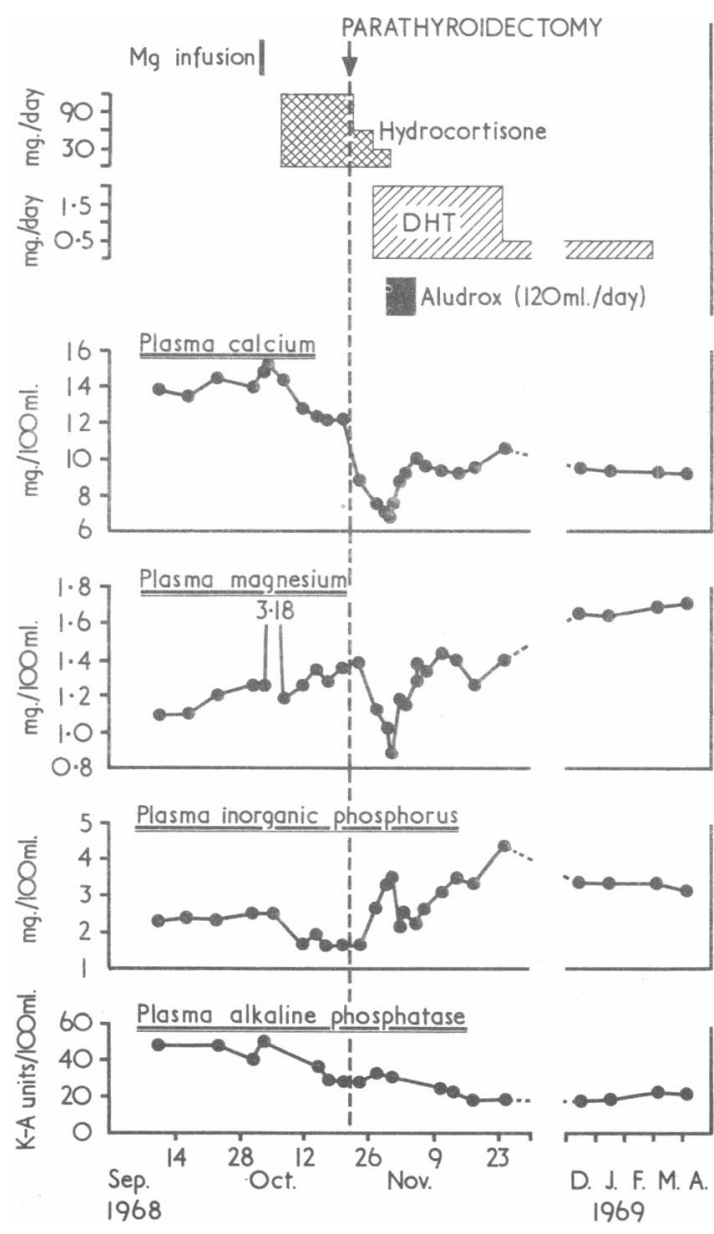

FIG. 3.-Plasma levels of calcium, magnesium, phosphorus, and alkaline phosphatase in patient before and after parathyroidectomy.

$\mathrm{ml}$. The dihydrotachysterol was stopped and after a further month the plasma calcium was unchanged, magnesium $1.73 \mathrm{mg} . / 100 \mathrm{ml}$., and alkaline phosphatase 21 King-Armstrong units $/ 100 \mathrm{ml}$. Her only symptoms at this time were some residual bone pains related to her Paget's disease; skeletal $x$-ray films had not changed since the parathyroidectomy.

\section{Comment}

In summary, this patient with Paget's disease and hyperparathyroidism had striking hypomagnesaemia preoperatively, associated with a normal urinary magnesium excretion. Magnesium, infused intravenously as magnesium sulphate, was not retained; it was rapidly and entirely lost in the urine. After parathyroidectomy there was a brief period of pronounced hypocalcaemia with further lowering of the plasma magnesium concentration. Four months after the operation both plasma calcium and plasma magnesium concentrations had returned to normal levels.

Two of the other hypomagnesaemic patients have been followed up for four or more weeks after parathyroidectomy. In one the plasma magnesium concentration had risen from 1.55 mg. $/ 100 \mathrm{ml}$. preoperatively to $1.69 \mathrm{mg}$. $/ 100 \mathrm{ml}$. at five weeks. The other patient had a plasma magnesium concentration of $1.10 \mathrm{mg} . / 100 \mathrm{ml}$., and a 24-hour urinary excretion of $120 \mathrm{mg}$. before operation. Four weeks after parathyroidectomy, at which time she was receiving oral magnesium supplements, the plasma level was $2.02 \mathrm{mg}$. $/ 100 \mathrm{ml}$. Two years later, when she had been off all treatment for one year, the plasma magnesium concentration was $1.73 \mathrm{mg} . / 100 \mathrm{ml}$. and the 24-hour urinary magnesium excretion $108 \mathrm{mg}$.

\section{Discussion}

The occasional occurrence of hypomagnesaemia in primary hyperparathyroidism has been noted previously (Harmon, 1956; Barnes et al., 1957; Agna and Goldsmith, 1958; Hanna et al., 1961) and is confirmed in this study, in which a significant negative correlation has been found between plasma calcium and magnesium concentrations in a group of patients with primary hyperparathyroidism. This is to be contrasted with the positive correlation which has been shown between the plasma calcium and magnesium concentrations in a group of normal subjects (Briscoe and Ragan, 1967). Patients with more severe primary hyperparathyroidism, manifested by higher plasma calcium concentrations, tend to have lower plasma magnesium concentrations.

In the patient studied in greatest detail striking hypomagnesaemia $(1.07 \mathrm{mg} . / 100 \mathrm{ml}$.) was associated with relatively high urinary magnesium losses $(85 \mathrm{mg}$./day). Parenterally administered magnesium was entirely excreted in the urine, indicating either that the hypomagnesaemia was not associated with any significant body deficit of magnesium or that if such a deficit was present it could not be corrected by an intravenous infusion of magnesium sulphate. After surgical correction of the hyperparathyroidism the plasma magnesium concentration rose to normal. It is of interest that the magnesium infusion resulted in a slight but definite rise in the plasma calcium concentration despite a considerable increase in urinary calcium output. In normal subjects the plasma calcium concentration falls during an intravenous infusion of magnesium sulphate (Jones and Fourman, 1966). In hypomagnesaemic subjects with associated hypocalcaemia, however, a rise of plasma calcium concentration accompanies magnesium administration (Heaton and Fourman, 1965; Zimmet et al., 1968). Hypomagnesaemia may interfere with the calcium-mobilizing effect of parathyroid hormone on the bone (Heaton and Fourman, 1965), and this would account for the effect of the magnesium infusion on the plasma calcium concentration in our patient.

Hanna et al. (1961) suggested that magnesium deficiency in hyperparathyroidism might be a result of excessive urinary magnesium losses accompanying hypercalciuria, since it is known that an acute increase in urinary calcium excretion, produced by an intravenous calcium infusion, is accompanied by increased urinary magnesium excretion, perhaps as a result of competition of calcium and magnesium for a common renal tubular reabsorptive pathway. Nevertheless, our five patients (all female) with plasma magnesium concentrations below 1.6 mg./100 ml., all of whom had urea retention (plasma levels 44-70 mg./100 ml.), had a mean daily urinary calcium excretion of $254 \mathrm{mg}$. Only one, the patient with a plasma calcium of 18.5 mg./100 ml., had a daily urinary calcium excretion exceeding $250 \mathrm{mg}$. Their mean daily urinary magnesium excretion of 65 $\mathrm{mg}$. was, by contrast, inappropriately high for a group of hypomagnesaemic subjects, since normal subjects will reduce the urinary magnesium losses to less than $12 \mathrm{mg}$./day before the plasma magnesium level falls significantly (see Fitzgerald and Fourman, 1956; Dunn and Walser, 1966).

Hypomagnesaemia associated with a relatively high urinary magnesium excretion in primary hyperparathyroidism cannot be attributed to the known effects of parathyroid hormone. Since the hormone increases renal magnesium reabsorption, it would be expected to cause hypermagnesaemia. Primary hyperparathyroidism, however, as well as other hypercalcaemic con- 
ditions, occasionally results in renal wasting of other substances, such as potassium (Sanderson, 1967) and amino-acids (Cusworth et al., 1970), which may be reversible when the hypercalcaemia is corrected. The defective renal conservation of magnesium in our patients, which was often associated with slight urea retention, may be a similar and sometimes reversible effect of primary byperparathyroidism.

I ain grateful to Professor C. E. Dent for advice in the preparation of this paper, and to Dr. Lyal Watson for continued guidance and encouragement. I also thank Mr. V. K. Asta for preparing the diagrams.

\section{REFERENCES}

Agna, J. W., and Goldsmith, R. E. (1958). New England fournal of Medicine, 258, 222.

Barnes, B. A., Krane, S. M., and Cope, O. (1957). Fournal of Clinical Endocrinology and Metabolism, 17, 1407

Briscoe, A. M., and Ragan, C. (1967). Nature, 214, 1126.

Bulger, H. A., and Gausmann, F. (1933). Fournal of Clinical Investigation, 12,1135 .

Care, A. D., Sherwood, L. M., Potts, J. T., jun., and Aurbach, G. D. (1966). Nature, 209, 55.
Clarkson, E. M. McDonald, S. J, de Wardener, H. E, and Warren, R (1965). Clinical Science, 28, 107

Cusworth, D. C., Dent, C. E., and Scriver, C. R. (1970). In preparation Davies, D. R., Dent, C. E., and Watson, L. (1968). Britich Medical fournal, 3, 395

Dent, C. E. (1962). British Medical foumal, 2, 1419.

Dent, C. E., Harper, C. M., and Philpot, G. R. (1961). Quarteriy fournal of Medicine, 30, 1

Dent, C. E., and Watson, L. (1968). Lancet, 2, 662.

Dick, M. (1967). Fournal of Clinical Pathology, 20, 216

Dunn M J. and Walser, M. (1966). Metabolism, 15,884.

Fitzgerald, M. G., and Fourman, P. (1956). Clinical Science, 15, 635

Hanna, S., North, K. A. K., MacIntyre, I., and Fraser, R. (1961). British Medical fournal, 2, 1253 .

Harmon, M. (1956). American Fournal of Diseases of Children, 91, 313.

Heaton, F. W. (1966). Quoted by L. N. Pyrah, A. Hodgkinson, and C. K. Anderson, British fournal of Surgery, 1966, 53, 245.

Heaton, F. W., and Fourman, P. (1965). Lancet, 2, 50.

Jones, K. H., and Fourman, P. (1966). Clinical Science, 30, 139.

MacDonald, M. A., and Watson, L. (1966). Clinica Chimica Acta, 14, 233.

Macintyre, I., Boss, S., and Troughton, V. A. (1963). Nature, 198, 1058

Reifenstein, E. C., Albright, F., and Wells, S. L. (1945). Fournal of Clinical Endocrinology, $5,367$.

Sanderson, P. H. (1967). British Medical fournal, 1, 679.

Shelp, W. D., Steele, T. H., Deluca, H. F., and Reiselbach, R. E. (1966). Clinical Research, 14, 448.

Steele, T. H., Wen, S.-F., Evenson, M. A., and Reiselbach, R. E. (1968). Fournal of Laboratory and Clinical Medicine, 71, 455.

Sutton, R. A. L., and Watson, L. (1969). Lancet, 1, 1000.

Zimmet, P., Breidahl, H. D., and Nayler, W. G. (1968). British Medical fournal, 1, 622 .

\title{
Practolol in Treatment of Supraventricular Cardiac Dysrhythmias
}

\author{
GRAHAM GENT,* M.A., M.B., B.CHIR. ; TIMOTHY C. DAVIS, $†$ M.B. \\ ALASTAIR MCDONALD, $\ddagger$ B.SC., M.R.C.P., M.R.C.P.ED.
}

$S^{\text {u }}$ ummary: Practolol (I.C.I. 50172) was used to treat supraventricular dysrhythmias in 32 patients with a rapid ventricular rate and with heart disease of varied aetiology. In 26 patients the average reduction in ventricular rate was 75 per minute, while immediate reversion to sinus rhythm occurred in three patients. The slowing effect was mainly due to a direct action on the atrioventricular node. The effectiveness of practolol was unrelated to the type of dysrhythmia or its aetiology. No serious adverse clinical effects were noted.

\section{Introduction}

Practolol (I.C.I. 50172) is a cardioselective beta-adrenergic receptor blocking drug with weak sympathomimetic properties (Barrett et al., 1967; Brick et al., 1968). It lacks local anaesthetic and quinidine-like actions and therefore has no direct depressant effect on the myocardium. The use of the drug in the management of supraventricular dysrhythmias has been encouraging (Gibson et al., 1968; Jewitt et al., 1969). We report here our clinical experience with intravenous practolol given to patients with supraventricular dysrhythmias associated with a rapid ventricular rate.

\footnotetext{
* Research Fellow

$\dagger$ Registrar.
$\ddagger$ Senior Registrar.

Cardiac Department, the London Hospital, London E.1
}

\section{Patients Studied}

Practolol was given to 32 patients (see Table) who had various cardiac lesions. Fifteen had rheumatic heart disease and four had undergone recent heart valve replacement-the mitral valve in three and both aortic and mitral valves in one. Three patients with calcific aortic stenosis had recently had aortic valve replacement. Ischaemic heart disease was the underlying cardiac lesion in seven patients, recent cardiac infarction having occurred in two. Six patients had prolonged attacks of paroxysmal tachycardia, associated with Wolff-Parkinson-White syndrome in four, and one patient had a fossa ovalis atrial septal defect. Clinical and radiological evidence of heart failure was present in 22 patients and in eight the failure was severe.

Practolol was injected intravenously with electrocardiographic control in a dose of $2 \mathrm{mg}$./minute until a therapeutic effect was noticed or a total of $20 \mathrm{mg}$. had been given.

\section{Results}

The response of the ventricular rate to practolol and the dosages required are shown in the Table. The effect of the drug was apparent within a few minutes of administration. The maximum dosage was $12 \mathrm{mg}$. in the 26 who responded, but usually the effective dose was between 5 and $10 \mathrm{mg}$. In six cases there was no response to the drug, the ventricular rate being unchanged after $20 \mathrm{mg}$. of practolol.

Atrial Fibrillation.-Before administration of practolol the 